\title{
Heavy containerised trucks creating pollution in transport of cars
}

\author{
Niranjan Mudliar ${ }^{1, *}$, Paramjeet Singh ${ }^{2}$ \\ ${ }^{1}$ Research Scholar, ${ }^{2}$ Research Supervisor, Rai University, Ahmedabad, Gujarat, India \\ *Corresponding Author: \\ Email: niranjan1966@yahoo.co.in
}

\begin{abstract}
This objective of study is intended to find the changing perception of general public on heavy containerized type of trucks specially used for transport of passenger cars in polluting the environment. This study will help logistics companies involved in shipment of goods through heavy containerized trucks to decide upon steps to be taken care for fast, safe and secure movement of goods alongside adhering to the pollution norms, so that the growth of these companies keeps on improving. Research conducted by me is descriptive in nature. Descriptive research has helped in developing the concept of established priorities, to divulge adequate information which helps in decision making and thus essential for making the study a success.

The operations of many transport companies like Maersk, TRP Logistics Pvt. Ltd., BLR Logistics (I) Ltd., Reliable Cargo Movers \& Packers and Rio Logistics Pvt. Ltd. etc. should adopt a better strategy for faster movement of cargo, reducing turnaround time and simultaneously satisfying the public and the government on environmental degradation issues. Best strategy will be to cover all areas like reducing idling time, better truck driving, faster product movement, quality deliveries in terms of reliability and of course reduction in exhaust gases harmful for environment. Once the conservative thought would diminish, definitely the transport sector will grow with leaps and bounds to ultimately benefit all stakeholders.
\end{abstract}

Keywords: Logistics, Transport, Environment, Pollution, Reliability, Driving, Defense.

\section{Introduction}

Transport Industry Profile: Road transport means commutation of goods and personnel from one place to the other on roads. Road is a route between two destinations, which has been either paved or worked on to enable transportation by way of motorised and nonmotorised carriages. The advantages of road transport in comparison to other means of transport are many, resulting in it being generally preferred mode. The investment required in road transport is very less compared to other modes of transport such as railways and air transport. The cost of construction, operating cost and maintaining of roads is cheaper than that of laying new railway lines.

Road transport system in India is having exceptional importance in economic development of the country. Road Transport can open up rural and remote areas of the country unreachable normally. In India various places still remain unconnected through railways, airways or water way like the upper reaches of Uttarakhand, Himachal Pradesh, West Bengal and North east. Under these circumstances road transport can easily access such remote areas where other means cannot penetrate. Road transport in India is contributing significantly towards the growth of gross domestic product of the country. In comparison to railways, road transport is more convenient, quicker and more adjustable. ${ }^{1}$ For short distance travel, motor is the ideal mode of transport as it can collect and drop passenger and goods at any place. Road transport can also give door to door service which railways cannot even think of, as the consignee has to take deliveries from nearest railway station making it inconvenient at times. Road transport can become complementary to railway and other modes of transport. It is only through feeder roads, railways can collect its passengers and goods easily. Railways cannot connect villages of the country without such roads, however road transport can easily connect railway stations with distant villages. Road transport is very much helpful to agricultural sector of the country as it provides easy and quick facilities for the marketing of agricultural produce especially fast perishable products like vegetables, fruits etc. It's the road transport which can help the farmers to bring their outputs to Mandis and also farm inputs like seeds etc. to the field. Road transport is very important for the industrial development of the country. Establishments of modern and heavy industries has become possible due to the construction of well-connected network of roads in the country. The North - South corridor and East - West Link Road are an example of increasing network of Roads. Road transport is generating huge number of employment in the country. Construction of roads is creating a great scope for employment as it can create a good number of man-days for ordinary labour. Road transport is important with reference to the defense sector too of the country. A sound defense mechanism can be maintained with the well-developed network of roads in border areas of the country. Construction of roads in inaccessible areas enables the defense force of the country to take control of such areas.

On the green initiatives front the ministry of road transport and highways ${ }^{2}$ has recommended a policy "Vehicle Fleet modernization program", wherein replacement of old, heavy commercial vehicles contributing maximum vehicular pollution will receive financial benefits like scrap value of discarded vehicle along with other incentives from OEMs apart from the incentives from government. 
The big drivers of global business have major influence towards commercial vehicle business. ${ }^{3}$

Several global scale trends related to climate protection, resources competition, social change and demographic shifts in particular are fundamentally changing the rules of competition for the truck industry. The concern about climate change coupled with environmental regulation has led to a new commitment to increase fuel efficiency and reduce emissions.

\section{Passenger Car Sector}

The Indian car industry has undergone a tremendous transformation in the last few years. Not only has the number of models of a particular brand has increased, but the volumes are also growing. The car manufacturers have to tap new markets, which mean they have to transport their sleek products to urban, semi-urban and rural destinations, most of which did not have existing road infrastructure. Therefore, the need to efficiently move passenger vehicles across the country, and onwards to ports for exports, has to be over-emphasized. Furthermore, with higher investment required to improve road infrastructure in order to sustain growth over the next upcoming decade, it is going to be imperative to strictly enforce truck - size and weight regulations to make optimum use of road investment. According to industry experts, 'Over laden axles on freeways would be detrimental to the pavements and necessitate significantly large maintenance budgets -- something that is clearly avoidable'.

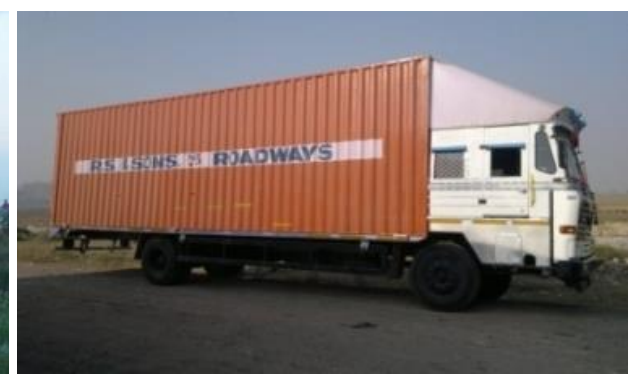

and BS VI standards. This has been hotly debated when the Supreme Court ordered for complete ban on sale of BS III standard vehicles with effect from 01 April $2017 .^{5}$

Vehicle safety, quality and its minimum handling capacity, along with transportation costs are key issues for deciding about utilizing containerization. The introduction of larger and faster Trailer trucks has made containerized shipment an economic viable alternative. Furthermore, since standard containers on trailers adhere to Central Motor Vehicle Rules, 1989 and restrictions like height, width etc, therefore car transport will now conform to the specifications. Capt. Rajakrishnan said Maruti (transports cars through carcarriers and trains) has shown a lot of interest in the product, which will be leased out to them. Similarly Honda, Mitsubishi and Ford are positive about the product. Industry experts feel that from a logistics services provider's perspective, the ability to utilize the existing freight containers to transport cars within the country will go a long way towards developing incremental business opportunities cars as well eliminating the high capital needs for customized transporters. Furthermore, the capability of maximum utilization of transportation assets by supply-chain links would improve performance as well as reduce costs, he said.

"On the export side, the ability to rapidly move cars into foreign markets using conventional liner shipping sources without waiting to aggregate larger lots for specialized car carriers will greatly assist the main content there is a comparison shown for BS III 
ability to reduce order-cycle times as well as current inventory carrying costs", said Capt. Rajakrishnan.

Environment literally means surroundings and everything that affect an organism during its lifetime. In another words "Environment is sum total of water, air and land around us, their interrelation ship among themselves and with the human being, plants and animals and property". Environmental studies by NEERI etc. opens an approach towards understanding of earth and the impact of human activities on environment. In order to cater to the increasing demand there is huge enlargement of human activity. After 1991 which saw LPG, to achieve economic progress, India too did not bother about environment and went ahead with cutting of trees, changing land usage, shrinking water bodies for expanding city dwellings and of course increasing the traffic movement. Air pollution is one such type of creation of increased Human activity that refers to contamination of air irrespective of outdoor or indoors activity. A physical, biological or chemical change in the atmosphere can be termed as air pollution. General perception is that pollution occurs due to release of harmful gases, dust, and smoke into atmosphere, making it difficult for plants, animals and humans to breathe clean air.

With the progress and development in the country, air pollution increase came along, which can be inside homes from chul has, commercial buildings having huge air conditioners or even the countryside. Consequently there has been an increase in various

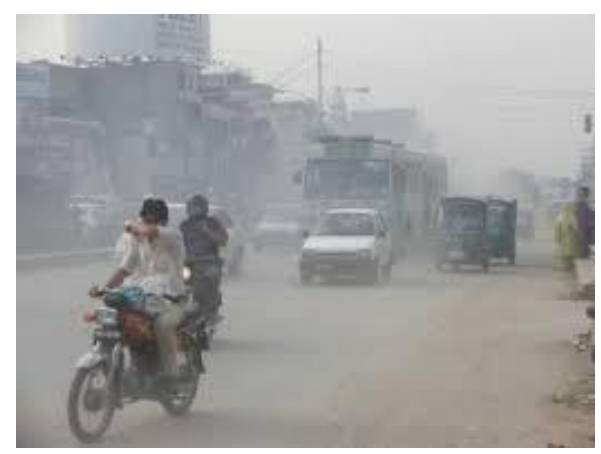

Fig. 2

The Supreme Court authorized Environment Pollution Control Authority (EPCA) in October 2016 and directed vehicle manufacturers that non BS IV will not be registered with effect from 01 April 2017 and gave time to these manufacturers to dispose off their BS III vehicles before that date. Moreover it was also expected that these vehicle manufacturers will stop producing BS III vehicle henceforth and also upgrade their production line with BS IV standards. An article in the Times of India clearly shows how the vehicle manufacturers flout such directives expecting that the Supreme Court will extend the deadline. They went to the court hoping for relief as they pleaded for allowing sale of BS III vehicles that has already been diseases caused by air pollution varying from breathing problem to lung cancer and finally incremental death rate. Air pollution not only affect people but also damages the whole ecosystem in which living things are harmed to such an extent that cause extinction in some cases. Air pollution has reached such an alarming stage that it affects the earth's atmosphere and allow more harmful radiation from the sun. Consequently, polluted atmosphere around earth has become an insulator which is preventing heat from escaping back. That is why there is a global rise in temperature which scientists refer to as "global warming". This rise in temperature affects world food supply and increasing sea level, increasing probability of tropical diseases. Presently earth is the only planet in the universe which is suitable for life. Air and water is needed for all living being's survival. Earth provides these essentials resources and man uses them. The over usage in long term has led to increasing pollution problems that is hazardous.

Many industries have come up owing to urbanization. Furthermore, there is an ever increasing demand of vehicles as means of commutation which are using fuels like petrol and diesel. Heavy amount of carbon monoxide, hydrocarbon, sulfur-dioxide and many more greenhouse gases are emitted in the air. The poisonous gases, chemicals and dust released into the air fall back on earth as acid rain harming crops and life. This has caused various harmful diseases.

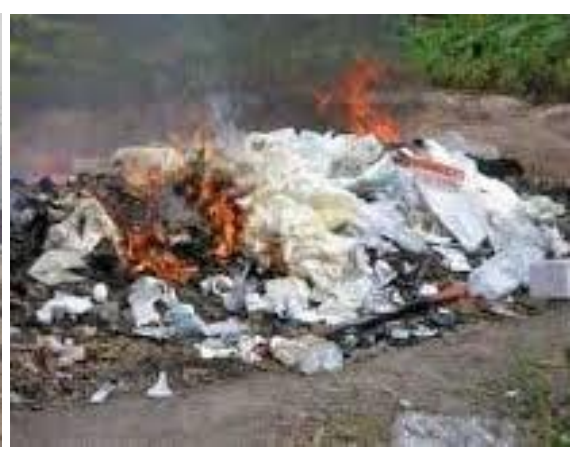

manufactured and dispatched to dealers. While their plea received support from central government, SC was in no mood to relent and it pressed for sale of only BS IV vehicles which are less polluting and more efficient after 01 April 2017. Top commercial vehicle manufacturers such as Tata motors, Ashok Leyland and Mahindra \& Mahindra and two wheeler majors like Hero Motors, Honda and TVS held near junk inventory worth over 12000 crore after Supreme Court disallowed sale and registration of BS III vehicles from April 1, 2017. ${ }^{6}$ These companies also faced wrath from their dealers who complained of inventory holding costs, possible default on bank loans taken to buy stocks and left with non-standard inventory. 
Table 1: BS III inventory of Top makers as on March 20, 2017

\begin{tabular}{|l|c|c|c|}
\hline \multicolumn{4}{|c|}{ Hitting Dead End } \\
\hline \multicolumn{2}{|c|}{ Commercial Vehicles: } & Two-Wheelers: \\
\hline Tata Motors & 45774 & Hero Motors & 297577 \\
\hline M\&M & 20824 & Honda & 225599 \\
\hline Ashok Leyland & 17449 & TVS & 78891 \\
\hline Total & 96724 & Total & 671305 \\
\hline Four Wheelers (Total) & 16198 & Three Wheelers (Total) & 40048 \\
\hline
\end{tabular}

Another article on the same topic covered the news about how the BS III inventory was disposed off by the dealers in Bhopal. After the SC announced ban on selling BS III vehicles from April 1, the dealers were in a spot regarding existing stock. ${ }^{7}$ It was not logical for them to wait for decision of manufacturers, so they announced discounts unilaterally according to affordability. Later the discounts were increased as manufacturers also chipped in to help clear off the stocks. Dealers for some two wheelers announced discount up to Rs. 25000/- by $30^{\text {th }}$ March 2017, but on witnessing massive crowds thronging their showrooms in Bhopal in a bid to cash in on heavy discounts being offered on BS III vehicles, they started reducing the discounts. Finally on $31^{\text {st }}$ they offered only Rs. 5000/-. A dealer had to close down the showroom on the last day as its stocks of BSIII exhausted and people were not ready to understand that the discount was only meant for these vehicles and not on new standard vehicles. A dealer said "Nobody was ready to listen; in view of the scenario we deemed it better to close the outlet on $31^{\text {st }}$ as we had exhausted entire stock of BSIII vehicles on the previous day itself".

BS or Bharat Standard for vehicles and the fuel used by them was formulated based on the emissions of vehicles and filtration process used to convert oil extracted from oil wells and converted into various petroleum products including the byproducts like Bitumen etc. These standards were similar to European Standards, Euro I, Euro II etc. BS III came into force in 2005 when two stroke engines were phased out as they were considered to be the most polluting engines and emitted all types of harmful gases. In 2010, BS IV was introduced and it took 7 years to finally implement it across the country that too due to directives of the Supreme Court. BS IV standards tightened further emissions limits of $\mathrm{NO}_{\mathrm{x}}$ and hydrocarbons. Under this standard auto manufacturers have to fit an "evaporative emission control unit" which reduces the amount of fuel that evaporates from a parked vehicle. This is all an attempt to keep Air Pollution under check.

\section{Materials and Methods \\ Cum Results}

Study of Data Related to Perception of Public with Respect to Transport Sector: For this study, a welldefined structured questionnaire has been prepared. For validating the questionnaire, reliability and validity of the items was examined as per explanation ahead. For

reliability this instrument has scored chronbach alpha value .65 and it is found that instrument is reliable enough. For validity two expert has examined this questionnaire and gave their nod for continuing this instrument.

Data has collected in offline mode, 50 candidates has filled this questionnaire after collecting the data sorting and tabulation of data is done in MS Excel and used for analysis purpose.

Data analysis has been compiled in the following table based on questions asked on various variables like preference of transport type, safety and security of transport type and engine compliances etc.

Table 2: Demographics of the respondents

Total $100 \%$

\begin{tabular}{|l|c|c|c|c|}
\hline S. No & Criteria & Occupation & Gender & Percentage \\
\hline 1 & Age $(20-25)$ & Students & Male & $15 \%$ \\
& & & Female & $5 \%$ \\
\hline 2 & Age $(26-35)$ & Service / Self employed & Male & $35 \%$ \\
& & & Female & $15 \%$ \\
\hline 3 & Age $(36-45)$ & Business / Top level Executives & Male & $20 \%$ \\
& & & Female & $10 \%$ \\
\hline
\end{tabular}

Note: Pie Charts and Graphs are made for the first two options only shown in the table as the third option is notional in nature. 
Table 3

\begin{tabular}{|c|c|c|c|c|c|c|}
\hline S. No. & $\begin{array}{c}\text { Preference on } \\
\text { type of } \\
\text { Transport } \\
\end{array}$ & Result & $\begin{array}{c}\text { Safety \& Security of } \\
\text { Material }\end{array}$ & Result & $\begin{array}{l}\text { Pricing of } \\
\text { Transport } \\
\text { affordable } \\
\end{array}$ & Result \\
\hline 1 & Road & $60 \%$ & Agree & $62 \%$ & Road & $58 \%$ \\
\hline 2 & Rail & $30 \%$ & Uncertain & $16 \%$ & Rail & $24 \%$ \\
\hline 3 & Air & $10 \%$ & Disagree & $12 \%$ & Air & $18 \%$ \\
\hline & Total & $100 \%$ & Total & $100 \%$ & Total & $100 \%$ \\
\hline Result & \multicolumn{2}{|c|}{$\begin{array}{l}\text { It is clear that maximum } \\
\text { people like Road Transport } \\
\text { to send their household } \\
\text { goods to the place they are } \\
\text { shifting etc }\end{array}$} & \multicolumn{2}{|c|}{$\begin{array}{l}\text { Some people are who not satisfied } \\
\text { (disagree) and are uncertain with the } \\
\text { safety issue comprise of a major chunk } \\
\text { of } 28 \% \text { and cannot be ignored. Sector } \\
\text { should improve its safety standards to } \\
\text { gain confidence of these people }\end{array}$} & \multicolumn{2}{|c|}{$\begin{array}{l}\text { Road Transport should } \\
\text { keep their prices affordable } \\
\text { in order to gain confidence } \\
\text { of public perception }\end{array}$} \\
\hline
\end{tabular}

Pie Charts given below is based on Result arrived in above table (first two options only): -

Pie Chart 1

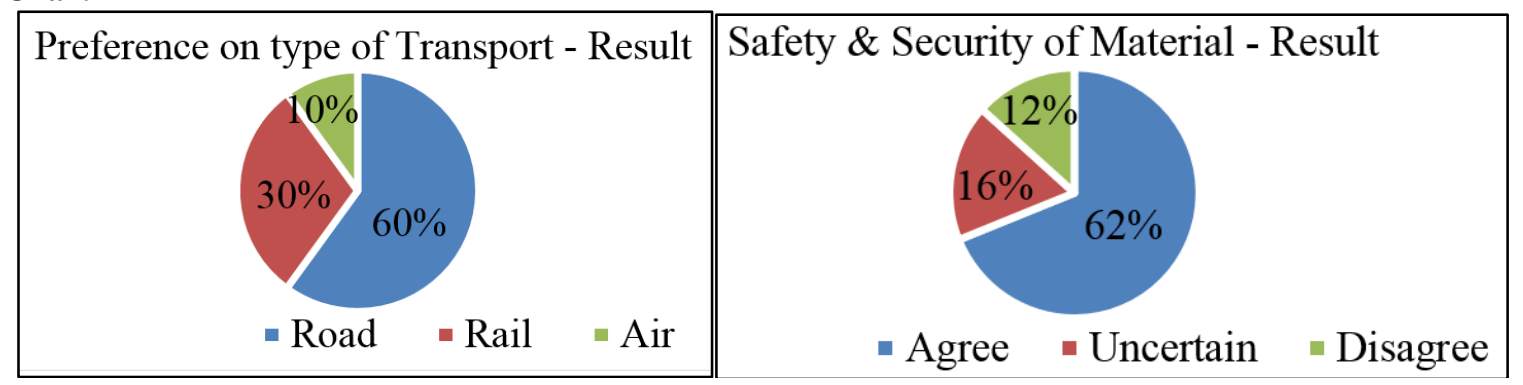

Table 4

\begin{tabular}{|c|c|c|c|c|c|c|}
\hline S. No. & $\begin{array}{l}\text { Knowledge of BS } \\
\text { Standards }\end{array}$ & Result & $\begin{array}{c}\text { Heavy } \\
\text { Containerized } \\
\text { trucks Environment } \\
\text { friendly }\end{array}$ & Result & $\begin{array}{c}\text { Heavy } \\
\text { Containerized } \\
\text { trucks fuel efficient }\end{array}$ & Result \\
\hline 1 & Known & $48 \%$ & Agree & $36 \%$ & Agree & $18 \%$ \\
\hline 2 & Uncertain & $16 \%$ & Uncertain & $50 \%$ & Uncertain & $30 \%$ \\
\hline 3 & Not known & $36 \%$ & Disagree & $4 \%$ & Disagree & $52 \%$ \\
\hline & Total & $100 \%$ & Total & $100 \%$ & Total & $100 \%$ \\
\hline Result & \multicolumn{2}{|c|}{$\begin{array}{l}\text { People should be made aware } \\
\text { about the standards, only then } \\
\text { we will be able to analyse the } \\
\text { problem being raised in this } \\
\text { assignment properly and } \\
\text { justifiably. Government has to } \\
\text { bring out details of these } \\
\text { standards through } \\
\text { advertisements and seminars } \\
\text { and workshops in which } \\
\text { awareness is increased over a } \\
\text { long period }\end{array}$} & \multicolumn{2}{|c|}{$\begin{array}{l}\text { Since almost } 54 \% \text { are either } \\
\text { uncertain or do not agree that } \\
\text { Truck engines are safe for } \\
\text { environment, it seems that the } \\
\text { general public has not been made } \\
\text { aware of their compliances by } \\
\text { either the manufacturers or the } \\
\text { government. So people will carry } \\
\text { general perception that heavy } \\
\text { containerized trucks are bad for } \\
\text { environment }\end{array}$} & \multicolumn{2}{|c|}{$\begin{array}{l}\text { General perception public } \\
\text { carries about containerized } \\
\text { trucks is that they are not fuel } \\
\text { efficient. This perception } \\
\text { must also be changed from } \\
\text { the manufacturer's side. The } \\
\text { old school of thought in this } \\
\text { regard must change and it } \\
\text { must be accepted that these } \\
\text { days as power of trucks are } \\
\text { increasing, their fuel } \\
\text { consumption per kilometer is } \\
\text { decreasing }\end{array}$} \\
\hline
\end{tabular}

Pie Charts given below is based on Result arrived in above table (first two options only): 


\section{Pie Chart 2}
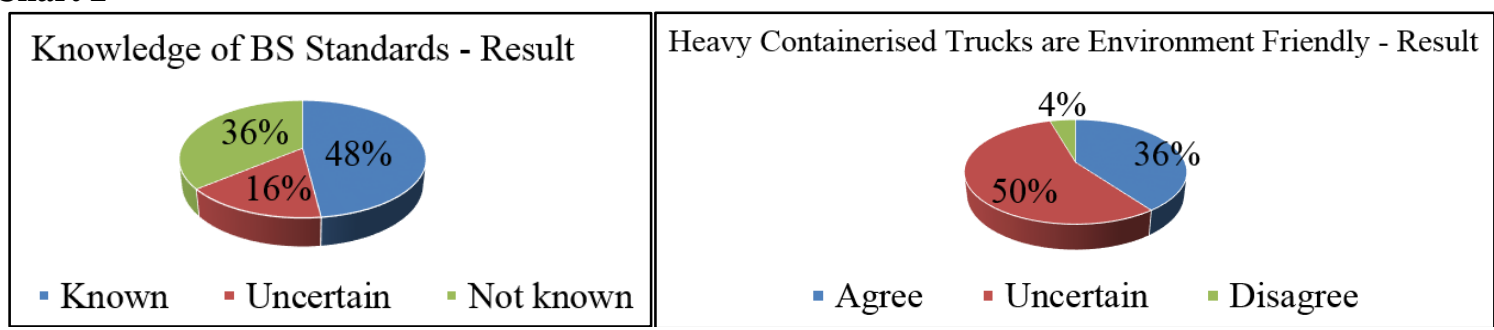

Table 5

\begin{tabular}{|l|c|c|c|c|c|c|}
\hline S. No. & $\begin{array}{c}\text { Heavy } \\
\text { Containerized } \\
\text { trucks are need } \\
\text { of future }\end{array}$ & Result & $\begin{array}{c}\text { Passenger Cars } \\
\text { transport through } \\
\text { Heavy Containerized } \\
\text { trucks }\end{array}$ & Result & $\begin{array}{c}\text { Passenger Cars transport } \\
\text { through Railways }\end{array}$ & Result \\
\hline 1 & Agree & $82 \%$ & Agree & $46 \%$ & Agree & $25 \%$ \\
\hline 2 & Uncertain & $10 \%$ & Uncertain & $30 \%$ & Uncertain & $26 \%$ \\
\hline 3 & Disagree & $8 \%$ & Disagree & $24 \%$ & Disagree & $49 \%$ \\
\hline Result & $\begin{array}{c}\text { Total } \\
\text { Containerized trucks are in } \\
\text { demand }\end{array}$ & $\begin{array}{c}\text { Total } \\
\text { It was clear that maximum of the } \\
\text { respondents have told that } \\
\text { passenger cars transport is not } \\
\text { economical through these type of } \\
\text { trucks as they can hardly hold 6 } \\
\text { to 10 hatchback type of cars, 4 to } \\
\text { 6 sedan type and 4 to 6 SUVs }\end{array}$ & $\begin{array}{c}\text { From the total of 50 respondents 10\% has } \\
\text { given the response as strongly agree and 14\% } \\
\text { have given agree with rail transport being } \\
\text { suitable mode of transporting passenger cars. } \\
\text { It seems that people understand that railways } \\
\text { prefer passenger trains over freight trains and } \\
\text { therefore they are slow in reaching } \\
\text { destinations. Moreover Rail network are not } \\
\text { covered up to several dealers destination }\end{array}$ \\
\hline
\end{tabular}

Graphs given below is based on Result arrived in above table (first two options only):

\section{Graph 1}

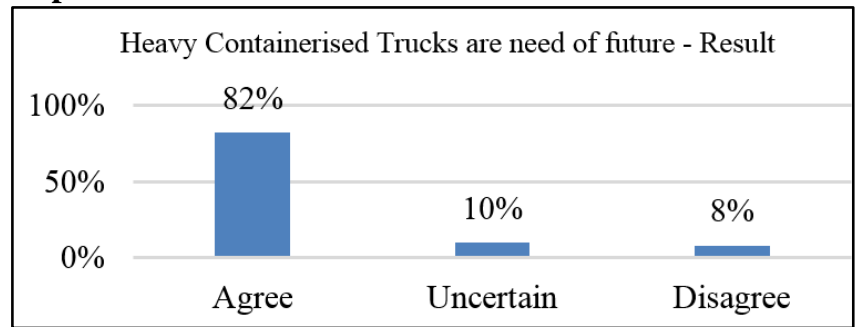

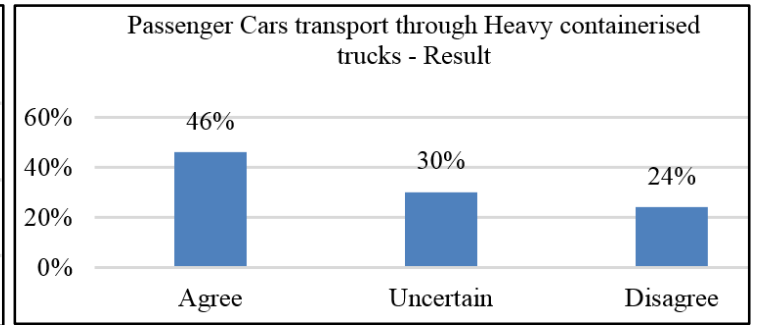

Table 6

\begin{tabular}{|c|c|c|c|c|c|c|}
\hline S. No. & $\begin{array}{c}\text { Road network } \\
\text { improvement will } \\
\text { help Heavy } \\
\text { Containerized trucks }\end{array}$ & Result & $\begin{array}{c}\text { Government } \\
\text { implementing BS VI } \\
\text { standards from } 2020 \\
\text { will reduce harmful } \\
\text { emissions }\end{array}$ & Result & $\begin{array}{l}\text { Passenger Cars } \\
\text { transport through } \\
\text { Waterways }\end{array}$ & Result \\
\hline 1 & Agree & $81 \%$ & Agree & $37 \%$ & Agree & $13 \%$ \\
\hline 2 & Uncertain & $11 \%$ & Uncertain & $30 \%$ & Uncertain & $47 \%$ \\
\hline \multirow[t]{2}{*}{3} & Disagree & $8 \%$ & Disagree & $33 \%$ & Disagree & $40 \%$ \\
\hline & Total & $100 \%$ & Total & $100 \%$ & Total & $100 \%$ \\
\hline Result & \multicolumn{2}{|c|}{$\begin{array}{l}\text { Once the Road network and } \\
\text { quality of Roads increase, the } \\
\text { fuel efficiency of heavy trucks } \\
\text { will automatically improve, this } \\
\text { will also reduce their emissions } \\
\text { and help the cities to be rid of air } \\
\text { pollution }\end{array}$} & \multicolumn{2}{|c|}{$\begin{array}{l}\text { Government has to sensitize the } \\
\text { public about Bharat Standards which } \\
\text { apply on emission control of } \\
\text { vehicles so the people can report of } \\
\text { non-compliance }\end{array}$} & \multicolumn{2}{|c|}{$\begin{array}{l}\text { Although the public has not } \\
\text { agreed with the new concept but } \\
\text { once its utility, safety, economical } \\
\text { pricing and environmental } \\
\text { friendly transport advantages } \\
\text { become popular, this will be the } \\
\text { most preferred type of transport. }\end{array}$} \\
\hline
\end{tabular}


Graphs given below is based on Result arrived in above table (first two options only):

\section{Graph 2}

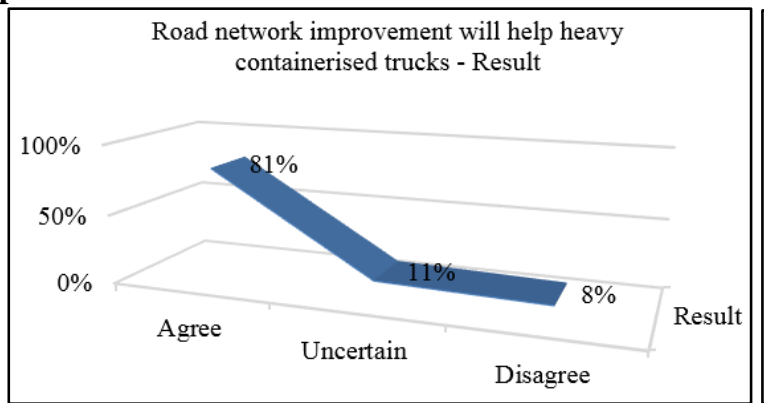

\section{Conclusion}

1. The faith of people in road transport should be improved by the sector.

2. Road Transport industry should bring down the prices of transportation and also issue promotional material comparing their prices with rail and air transport.

3. Government should advertise environmental standards for road vehicles so that when someone is seen running engines emitting gases, should be immediately penalized.

4. Truck engines these days have become fuel efficient and this fact should be brought to the notice of courts and general public by manufacturers. BS VI is an example of fuel efficient engines.

5. Heavy containerized trucks should be directly assembled with light weight material to make them more fuel efficient as well as research should be encouraged to reduce emissions.

6. Containerized trucks should be preferred for transport of goods.

7. Design changes to be incorporated for accommodating more passenger cars in a containerized truck so that is becomes less costly, more efficient transportation as well as reaching destinations where there is no rail or air connectivity.

8. Government should support truck manufacturers in research work to bring out fuel efficient and environmental friendly engines.

9. Courts should take a lenient view on environmental issues for road transport as containerized trucks are the need of the hour and a major contributor for the economic progress of the country.

\section{References}

1. Saha Prakash Kumar. Essay on Road Transport System in India., Economicdiscussion.net - accessed date $28 / 05 / 2017$

2. The Ministry of Road Transport \& Highways - Year End Review - 2016, website of Press Information Bureau of the Government of India, http://pib.nic.in/newsite/PrintRelease.aspx?relid=155892, accessed date 27/12/2017

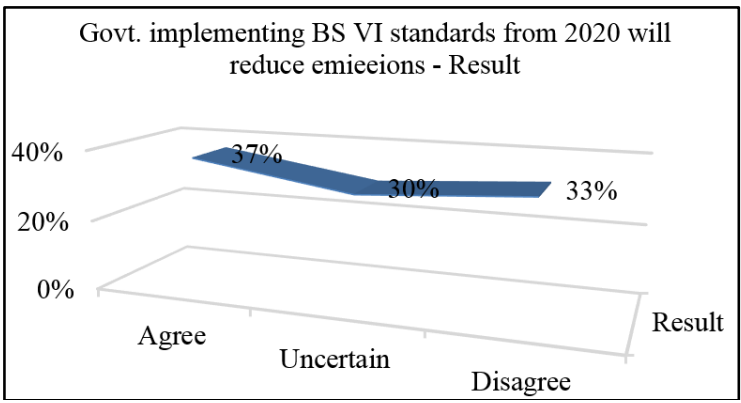

3. Ruger Michael W, Vernersson Fredrik and Brash Colin. The Truck industry in 2020 - How to move in moving markets. Strategy \& - PWC, Nov 6, 2014.

4. Simhan Raja T. E. A Container for Cars., The Hindu Business Line, dated 08/05/2000, www.thehindubusinessline.com/2000/05/08/stories/09087 1rs.htm, accessed date 28/05/2017

5. Bharat Stage Emission norms, BSIII Ban, BSIV and BSVI Norm, be money aware dated 31 mar 2017, https://www.bemoneyaware.com/blog/bharat-stage-bsemission-norms-bsiii-bsiv-bsvi/,accessed date 27122017

6. Doval Pankaj. SC Ban: Auto industry Stuck with inventory worth Rs. 12k Crore., The Times of India, Bhopal (page11), dated 30/03/2017

7. BS III Scramble: Only few get Lucky. Times News Network, The Times of India, Bhopal (page 2), dated 01/04/2017 